\title{
Changes in the properties of grassland soils as a result of afforestation
}

\author{
Milosz Podwika ${ }^{(1)}$, \\ Katarzyna Solek-Podwika ${ }^{(2)}$, \\ Krystyna Ciarkowska ${ }^{(3)}$
}

\begin{abstract}
The effects of afforestation on physical, physico-chemical, and biological properties of grassland soils were investigated in three sites $(215-230 \mathrm{~m}$ a.s.l.) located within the urban area of Krakow (southern Poland) after 45-60 years since the introduction of forest tree species. We compared the contents of nutrients and the composition of humus between forest and adjacent grassland soils, as well as the quality of the forest soils in relation to the introduced tree species (alder, pine, oak, birch, maple, elm). We hypothesized that afforestation of grassland soils results in the increase of acidity and nutrient contents. Studied soils belong to Dystric Gleysols (forest) and Eutric Gleysols (grassland). Overall, 168 soil samples were taken from two layers $(0-10 \mathrm{~cm}$ and $10-30 \mathrm{~cm})$ both from forest and grassland soils. The results showed an increase of organic carbon (up to $150 \%$ ), total nitrogen (up to $70 \%$ ) and total acidity (up to 18 times), as well as a decrease of $\mathrm{pH}$ (up to 40\%) and activity of dehydrogenase (up to $60 \%$ ) in forest soils in relation to the respective grassland soils. The most intensive changes were observed in the topsoil layers $(0-10 \mathrm{~cm})$. We also calculated the Soil Quality index (SQI) based on PCA in which only soil parameters with high load factors were taken into consideration. SQI ranged from 0.39 to 0.41 in grassland soils and from 0.33 to 0.37 in forest soils. Among for est soils, the highest value of SQI was obtained for stands dominated by black alder, indicating that such species is the most suitable for afforestation purposes under the study conditions. The results may be helpful in the realization of afforestation plans of humid grassland soils.
\end{abstract}

Keywords: Land Use Change, Physico-chemical Soil Properties, Soil Quality Index

i.e., $4.4 \%$ of the total land area. This coverage is one of the lowest in Poland (CSO 2015). Landscape and geomorphological structure in Krakow and its surroundings are very heterogeneous. There are Jurassic and Cretaceous formations (limestone, marl), Tertiary formations (Miocene clay) and Quaternary formations of sand, gravel and clay (Aleksandrowicz \& WrochniakStopka 1959).

In this area, afforestation of grasslands carried out in 1955, 1965 and 1970 has created forest complexes (secondary communities) characterized by small areas, lack of spatial continuity and long distances from older forest stands. These features affect the floral composition of forest communi- $\square$ (1) Local Park and Zoological Garden - Fundation ul. Kasy Oszczednosci Miasta Krakowa 14, 30-232 Kraków (Poland); (2) Soil Science and Soil Protection Department, Institute of Soil Science and Agrophysics, University of Agriculture in Krakow, Aleja Mickiewicza 21, 31-120 Krakow (Poland)

@ Katarzyna Solek-Podwika (rrpodwik@cyf-kr.edu.pl)

Received: Jul 18, 2017 - Accepted: Jun 28, 2018

Citation: Podwika M, Solek-Podwika K, Ciarkowska K (2018). Changes in the properties of grassland soils as a result of afforestation. iForest 11: 600-608. - doi: 10.3832/ifor2556-011 [online 2018-09-25]

Communicated by: Gianfranco Minotta ties leading to the depletion of forest flora (CSO 2014). Initially, the afforestation was performed on the poorest sandy meadows and wastelands. In recently afforested areas, carbon content increases with time and this results in substantial carbon storage (Ross et al. 1999, Innangi et al. 2017). However, at an early stage of the new forest growth, the accumulation of carbon is relatively slow, but this process can noticeably accelerate after several decades (Smal \& Olszewska 2008, Tanner et al. 2014). Accumulation of carbon in forest soils depends on the age of trees, species introduced during afforestation and the fertility of soil environment (Gonet et al. 2009, Holubík et al. 2014). Afforestation also results in soil acidification which depends on the tree species, increasing with time passed since afforestation. Some tree species such as the black alder (Alnus glutinosa L.) are symbiontic with Frankia alni, a nitrogen-fixing bacteria living in root nodules (Claessens et al. 2010), and may enrich the soil with nitrogen (Temperton et al. 2003). It is estimated that approximately $30-130 \mathrm{~kg} \mathrm{~N}$ $\mathrm{ha}^{-1}$ year-1 of fixed nitrogen enters the soil as the result of alder leaf fall (Claessens et al. 2010, Jonczak et al. 2016). Jonczak et al. (2015) observed a higher decomposition rate of alder leaves, which are rich in nitrogen, as compared with maple, oak and beech leaves.

Previous studies on the impact of alder 


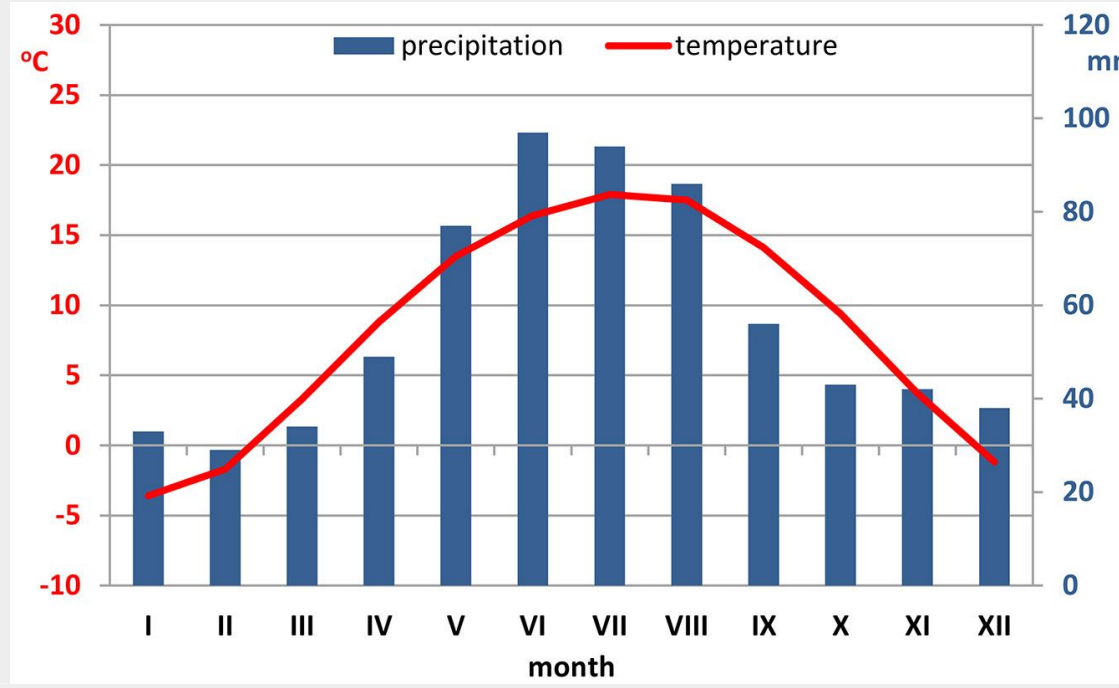

Fig. 1 - Ombrothermic diagram of the study area based on meteorological data (last decade - https://pl.climate-data.org/location/715022).

on soil properties have shown an increase in available phosphorus and magnesium (Brozek \& Wanic 2002, Orczewska et al. 2012), which improves the fertility of poor forest habitats and accelerates elements cycling in the ecosystem. Giardina et al. (1995) and Claessens et al. (2010) regard the alder as a "biological fertilizer". It is often used as a pioneer species during the establishment of new forests on reclaimed post-industrial areas, as well as to improve the trophic conditions of land designated for afforestation (Brozek \& Wanic 2002, Krzaklewski et al. 2012, Miletić et al. 2012, Mishra et al. 2016). Moreover, the black alder is well-adapted to grow and develop in humid ecosystems (Claessens et al. 2010). According to CSO (2015), the black alder occurs in approximately $5.3 \%$ of Polish forests. the introduction of forests on sandy soils of grassland habitats, an increase in the soil acidification and an accumulation of nutrients, especially organic carbon and total nitrogen occurs. A species increasing these parameters is the black alder which in the studied areas constitutes about $25-80 \%$ out of all tree species. influence of forest stands on grassland soil properties. We compared the contents of forestation.
It is assumed that about 50-60 years after

The aim of the study was to evaluate the

nutrients and the composition of humus between forest and adjacent grassland soils, as well as the quality of the forest soils in relation to the introduced tree species. Our assumption was that differences in the properties between forest and grassland soils could be attributed to the influence of tree species introduced by af-

\section{Materials and methods}

\section{Study area}

Krakow is located in southern Poland, on the Vistula River $\left(50^{\circ} 03^{\prime} 41^{\prime \prime} \mathrm{N}, 19^{\circ} 56^{\prime} 18^{\prime \prime}\right.$ E). The climate is mild and warm, with a mean annual temperature of about $9{ }^{\circ} \mathrm{C}$. The sum of annual precipitation ranges between 650 and $700 \mathrm{~mm}$ with the maximum rainfall in July (Fig. 1). The prevailing winds are western and south-western, depending on both the general circulation and the local winds along the valley of the Vistula river (Matuszko 2007 - https://pl.climatedata.org/location/715022).

The study area is flat with elevation ranging 215-230 $\mathrm{m}$ a.s.l. The soil cover was developed from Quaternary, water-bearing, fluvioglacial sands deposited on Miocene clays. Forest soils belonged to Dystric Gleysols and grassland soils belonged to Eutric Gleysols (WRB 2015) and were char-

Tab. 1 - Characteristics of studied A horizons in the soil of forest and grassland study sites.

\begin{tabular}{llccl}
\hline Habitat & Sites & $\begin{array}{c}\text { Thickness } \\
\text { range }(\mathrm{cm})\end{array}$ & $\begin{array}{c}\text { Colour } \\
\text { (Munsell chart) }\end{array}$ & Structure \\
\hline Grassland & G1 & $28-32$ & 10 YR3/2 - 3/3 & granular/ crumb \\
& G2 & $27-35$ & $10 Y R 4 / 2-4 / 3$ & granular / crumb \\
& G3 & $29-33$ & $10 Y R 2 / 1-2 / 2$ & granular / crumb \\
Forest & F1 & $27-34$ & $10 Y R 3 / 1-2 / 1$ & crumb \\
& F2 & $28-33$ & $10 Y R 4 / 3-4 / 4$ & crumb \\
& F3 & $28-32$ & 10YR 3/2 $-3 / 3$ & crumb \\
\hline
\end{tabular}

acterized by elevated levels of ground water. Organic horizons 2-3 cm deep occurs only in stands with Pinus sylvestris. Within the A horizon of forest and grassland soils the layers $0-10 \mathrm{~cm}$ and $10-30 \mathrm{~cm}$ are separated. The characteristics of the whole $A$ horizons is presented in Tab. 1.

Forest (F) and adjacent grassland (G) soils were sampled at three sites located within the boundaries of Krakow urban area (Fig. 2): Borek Falecki (area 1: F1, G1), Skalki Twardowskiego (area 2: F2, G2), and Skotniki (area 3: F3, G3).

The first sampling site (2.30 ha) is a $\sim 60$ year old tree stand (F1) in Borek Falecki, with stand density of 603 tree ha-1 and the following specific composition: Pinus sylvestris L. (30\%), Alnus glutinosa L. (25\%), Quercus robur L. (25\%), Betula pendula Roth. (20\%). In the undergrowth Prunus serotina Ehrt., Padus avium Mill., and Sambucus nigra $L$. are predominant. The average loss of pine needles was $14 \%$, and for deciduous species the average loss of the assimilation apparatus was $8 \%$. According to the Forest Protection Instruction (FPI 2012) a slight defoliation was determined for pine, no defoliation for deciduous species.

The second sampling site ( $1.60 \mathrm{ha})$ is a 50-year old tree stand (F2) in Skalki Twardowskiego, with stand density of 646 tree $\mathrm{ha}^{-1}$. This area was covered by the following species: Alnus glutinosa L. (25\%), Acer pseudoplatanus L. (25\%), Acer platanoides L. (20\%), Betula pendula Roth. (20\%) and UImus laevis Pall. (10\%). In the undergrowth Sambucus nigra L. predominated. The average loss of the assimilation apparatus was $6 \%$. According to FPI (2012) no defoliation was determined.

The third research sampling site (2.60 ha) is a 45-year old tree stand (F3) in Skotniki, with stand density of 706 tree ha ${ }^{-1}$. The following species were determined in the vegetation cover: Alnus glutinosa L. (80\%), Betula pendula Roth. (20\%). In the undergrowth there were mainly Crataegus oxycantha L., and Sambucus racemosa L. The average loss of the assimilation apparatus was $5 \%$. According to FPI (2012) no defoliation was determined.

Grassland vegetation communities ( $\mathrm{G}_{1}$ G3) belonged to the same Molinio-Arrhenatheretea class. In G1 (2.1 ha) Cirsium rivulare (Jacq.) All., Caltha palustris L., Polygonum bistorta L., Cirsium oleraceum L. Scop., and Festuca pratensis Huds. were the dominating species. In G2 (1.7 ha) Succisa pratensis, Molinia caerulea, Cirsium rivulare (Jacq.) All., Caltha palustris L., and Galium borealne dominated, and in $\mathrm{G}_{3}$ (2.4 ha) Molinia caerulea, Galium boreale, Succisa pratensis, Serratula tinctoria, Gladiolus imbricatus, and Dianthus superbus were the dominant species (Niemyska-Lukaszuk et al. 2001).

\section{Sampling and laboratory analyses}

For the purpose of this study, pairs of adjacent grassland and forest soils were se- 
lected. The investigated soils were under identical climate conditions and had the same system of water relations. The relief was also similar as well as the geological origins of the bedrock, which resulted in similar texture (Tab. 2). The soil properties before the change of land use (from grasslands to forests) were similar, which allows to consider the grassland soils as reference soils (Niemyska-Lukaszuk et al. 2001).

Species composition at each site was assessed by the use of randomly scattered squares $(20 \times 20 \mathrm{~m})$, separated by a distance of several meters. In each studied forest stand and grassland, seven squares were designated. In addition, two soil pits were made on each square in order to collect soil samples for analyses. Fourteen soil pits were made in each forest stand ( $\left.\mathrm{F}_{1}-\mathrm{F}_{3}\right)$ and on each meadow ( $\left.\mathrm{G}_{1}-\mathrm{G}_{3}\right)$, totaling 84 soil pits. Soil samples were taken from two layers: (i) $0-10 \mathrm{~cm}$, and (ii) $10-30 \mathrm{~cm}$, in both grassland and forest soils.

\section{Methods}

Soil texture was estimated by the densimetric-sieve method and classified according to WRB recommendations (WRB 2015). $\mathrm{pH}$ was measured potentiometrically in $1 \mathrm{M}$ potassium chloride using a soil/solution ratio as 1:2.5 (Tan 2005). Organic carbon ( $C_{\text {org }}$ ) and total nitrogen $\left(\mathrm{N}_{\text {tot }}\right)$ were estimated with a CNS analyzer (LECO $2000^{\circledR}$, LECO Corp., St. Joseph, MI, USA). The ratio of organic carbon to total nitrogen $(C / N)$ was then calculated.

Soil organic matter (SOM) division in fractions of different density and solubility was performed according to the method by Duchaufour \& Jacquin (1966) and was preceded by the separation of SOM in two fractions: (i) a light fraction with density $<2$ $\mathrm{kg} \mathrm{dm}^{-3}$, defined as the residue ( $\mathrm{Re}$ ); and (ii) a dense fraction with density $>2 \mathrm{~kg} \mathrm{dm}^{-3}$, using bromoform ( $\left.2 \mathrm{~kg} \mathrm{dm}^{-3}\right)$ according to Monnier et al. (1962). The dense fraction was subject to subsequent extractions ( extraction: mixture $0.1 \mathrm{~mol} \mathrm{dm}^{-3} \mathrm{Na}_{4} \mathrm{P}_{2} \mathrm{O}_{7}$

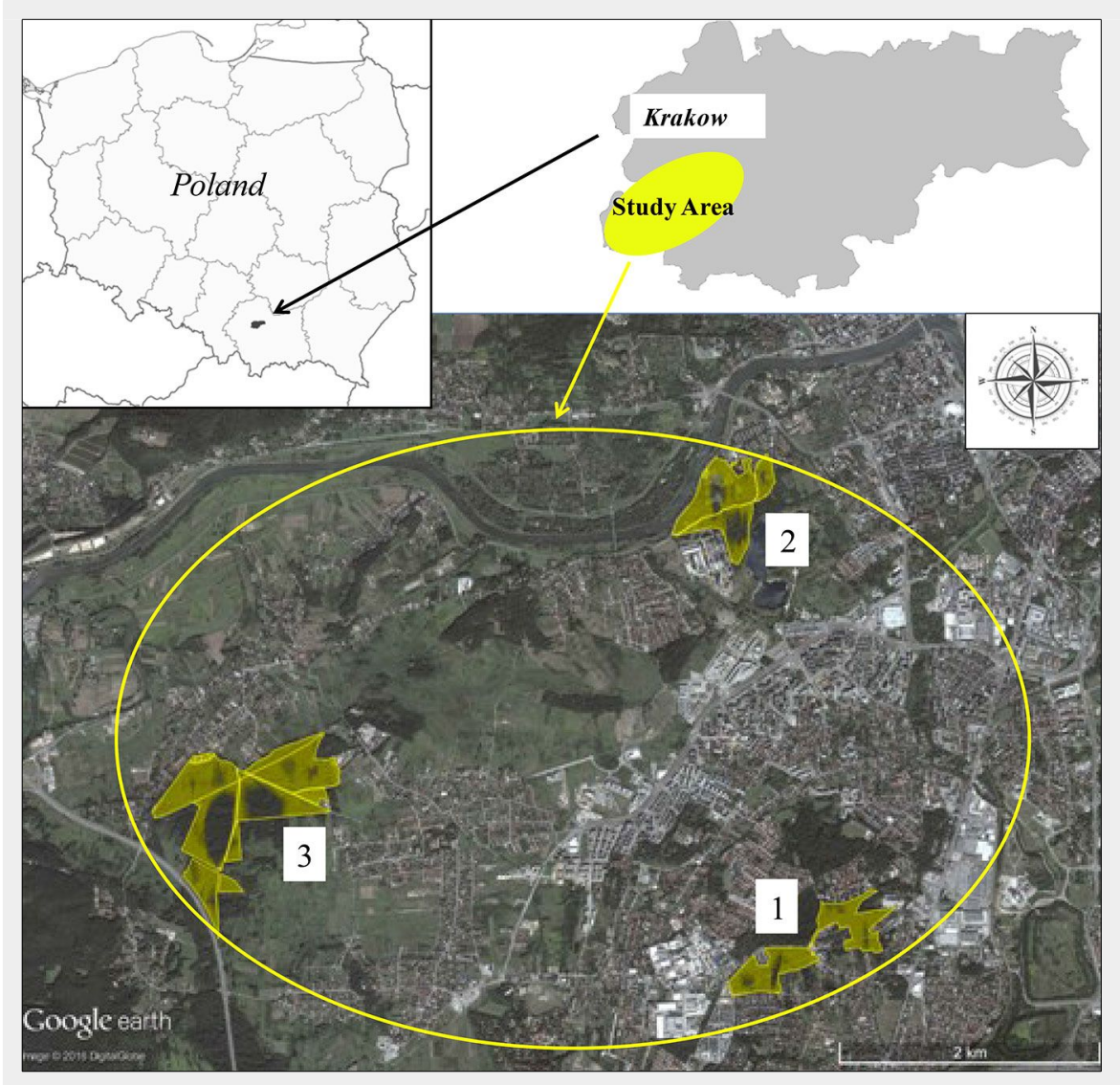

Fig. 2 - Location of the study area (Krakow, southern Poland) with indication of the three study sites where soil samples were taken. (1): Borek Falecki; (2): Skalki Twardowskiego; (3): Skotniki.

and 7.5\% $\mathrm{Na}_{2} \mathrm{SO}_{4}$; II extraction: $0.1 \mathrm{~mol} \mathrm{dm} \mathrm{m}^{-3}$ $\mathrm{Na}_{4} \mathrm{P}_{2} \mathrm{O}_{7}$; III extraction: $\mathrm{NaOH}$ ) to isolate humic acid $(\mathrm{H})$ and fulvic acid (F) on the basis of differences in their solubility. Humines $\mathrm{Hu}$ ) remained as non-extracted residues of the dense fraction. $C$ content in all fractions was determined by the automatic CNS analyser $\left(\operatorname{LECO} 2000^{\circledR}\right)$. The ratio of humic acid carbon to fulvic acid carbon (H:F) was calculated. Humification degree ( $\mathrm{Hd} \%)$ was calculated as a ratio of the sum of: hu- mic acid C, fulvic acid C, humines $C$ and humic acid $C$, fulvic acid $C$, humines $C$, residue C expressed in \%, as follows: (Ciarkowska et al. 2017 - eqn. 1):

$$
H d \%=\frac{H+F+H u}{H+F+H u+R e} \cdot 100
$$

Composition of sorption complex was established through the determination of exchangeable basic cations $\left(\mathrm{Ca}^{2+}, \mathrm{Mg}^{2+}, \mathrm{Na}^{+}\right.$ and $\mathrm{K}^{+}$) in the $1 \mathrm{~mol} \mathrm{dm}^{-3} \mathrm{NH}_{4} \mathrm{OAc}$ ( Tan

Tab. 2 - Physical and physico-chemical properties (mean \pm standard deviation) in layers $0-10 \mathrm{~cm}$ and $10-30 \mathrm{~cm}$ of differently used soils. Different letters indicate significant $(\mathrm{p}<0.05)$ differences between mean values. $(\mathrm{Hh})$ : total acidity $\left[\mathrm{mmol}{ }^{(+)} \mathrm{kg}\right] ;(B C):$ basic cations [mmol $\left.{ }^{(+)} \mathrm{kg}\right] ;(\mathrm{BS})$ : base saturation [\%].

\begin{tabular}{|c|c|c|c|c|c|c|c|}
\hline \multirow{2}{*}{ Layer } & \multirow{2}{*}{ Property } & \multicolumn{2}{|c|}{ Borek Falecki (area 1) } & \multicolumn{2}{|c|}{ Skalki Twardowskiego (area 2) } & \multicolumn{2}{|l|}{ Skotniki (area 3) } \\
\hline & & Grassland (G1) & Forest (F1) & Grassland (G2) & Forest (F2) & Grassland (G3) & Forest $(\mathrm{F} 3)$ \\
\hline \multirow[t]{7}{*}{$0-10 \mathrm{~cm}$} & $2.0-0.05[\%]$ & $88 \pm 2$ & $88 \pm 1$ & $90 \pm 1$ & $92 \pm 1$ & $87 \pm 2$ & $88 \pm 2$ \\
\hline & $0.05-0.002[\%]$ & $7 \pm 2$ & $6 \pm 1$ & $5 \pm 1$ & $5 \pm 1$ & $9 \pm 2$ & $7 \pm 2$ \\
\hline & $<0.002[\%]$ & $5 \pm 2$ & $6 \pm 1$ & $5 \pm 1$ & $3 \pm 1$ & $4 \pm 2$ & $5 \pm 2$ \\
\hline & $\mathrm{pH}_{1 \mathrm{M} \mathrm{KCl}}$ & $5.71 \pm 0.03^{a}$ & $3.80 \pm 0.05^{b}$ & $5.43 \pm 1.22^{a}$ & $4.13 \pm 0.04^{b}$ & $4.45 \pm 0.03^{a}$ & $3.69 \pm 0.01$ \\
\hline & $\mathrm{Hh}$ & $3.61 \pm 0.10^{a}$ & $61.36 \pm 1.92^{b}$ & $1.61 \pm 0.05^{a}$ & $25.35 \pm 2.87^{b}$ & $6.80 \pm 0.39^{a}$ & $68.05 \pm 3.05^{b}$ \\
\hline & BC & $49.26 \pm 3.66^{a}$ & $10.78 \pm 0.55^{b}$ & $40.67 \pm 0.52^{a}$ & $18.19 \pm 1.62^{b}$ & $46.75 \pm 1.33^{\mathrm{a}}$ & $15.95 \pm 0.63^{b}$ \\
\hline & BS & $92.48 \pm 0.60^{a}$ & $14.53 \pm 0.26^{b}$ & $96.19 \pm 0.12^{a}$ & $41.88 \pm 4.26^{b}$ & $87.12 \pm 0.33^{a}$ & $18.99 \pm 0.14^{b}$ \\
\hline \multirow[t]{7}{*}{$10-30 \mathrm{~cm}$} & $2.0-0.05[\%]$ & $88 \pm 1$ & $88 \pm 1$ & $90 \pm 2$ & $92 \pm 1$ & $87 \pm 2$ & $88 \pm 1$ \\
\hline & $0.05-0.002[\%]$ & $7 \pm 1$ & $6 \pm 1$ & $5 \pm 1$ & $5 \pm 1$ & $9 \pm 1$ & $7 \pm 1$ \\
\hline & $<0.002[\%]$ & $5 \pm 1$ & $6 \pm 1$ & $5 \pm 1$ & $3 \pm 1$ & $4 \pm 1$ & $5 \pm 1$ \\
\hline & $\mathrm{pH}_{1 \mathrm{M} \mathrm{KCl}}$ & $6.09 \pm 0.05^{\mathrm{a}}$ & $3.89 \pm 0.03^{b}$ & $5.67 \pm 0.03^{a}$ & $4.49 \pm 0.01^{b}$ & $4.53 \pm 0.04^{\mathrm{a}}$ & $3.69 \pm 0.02^{b}$ \\
\hline & $\mathrm{Hh}$ & $1.97 \pm 0.05^{a}$ & $36.00 \pm 1.40^{b}$ & $1.56 \pm 0.08^{a}$ & $16.02 \pm 1.72^{b}$ & $6.61 \pm 0.34^{a}$ & $36.77 \pm 0.85^{b}$ \\
\hline & $B C$ & $43.79 \pm 0.14^{a}$ & $11.04 \pm 0.53^{b}$ & $45.88 \pm 0.69^{a}$ & $11.72 \pm 0.31^{b}$ & $51.48 \pm 1.51^{a}$ & $17.24 \pm 1.03^{b}$ \\
\hline & BS & $93.52 \pm 0.08^{a}$ & $23.46 \pm 0.73$ & $96.71 \pm 0.20^{a}$ & $42.38 \pm 2.38^{b}$ & $88.63 \pm 0.45^{a}$ & $31.91 \pm 1.51^{b}$ \\
\hline
\end{tabular}


2005) and total acidity ( $\mathrm{Hh}$ ) was determined using $1 \mathrm{M} \mathrm{Ca}\left(\mathrm{CH}_{3} \mathrm{COO}\right)_{2}$ at $\mathrm{pH} 8.2$ (Ostrowska et al. 1991). Contents of determined basic cations were summed up and presented as a total content of basic cations (BC). Cation exchange capacity $(C E C=B C+H h)$ and base saturation (BS = BC / CEC - 100\%) were also calculated (Ciarkowska et al. 2017).

Available phosphorus $\left(\mathrm{P}_{\mathrm{av}}\right)$ and potassium $\left(\mathrm{K}_{\mathrm{av}}\right)$ were extracted using $0.03 \mathrm{M} \mathrm{CH}_{3^{-}}$ $\mathrm{COOH}$ buffered solution according to Egner and Riehm's method, while available magnesium $\left(\mathrm{Mg}_{\text {av }}\right)$ was extracted using $0.02 \mathrm{M} \mathrm{CaCl}_{2}$ solution following the Schatschabel's method (Gorlach \& Mazur 2001). Contents of both exchangeable $\left(\mathrm{Ca}^{2+}, \mathrm{Mg}^{2+}\right.$, $\left.\mathrm{Na}^{+}, \mathrm{K}^{+}\right)$and available $\left(\mathrm{P}_{\mathrm{av}}, \mathrm{K}_{\mathrm{av}}, \mathrm{Mg}_{\mathrm{av}}\right)$ cations in obtained solutions were determined with inductively coupled plasma atomic emission spectrometry (ICP-OES JY 238 ULTRACE $^{\circledR}$, Horiba, Edison, NJ, USA).

Dehydrogenase activity (DHA) was determined following the method of Casida et al. (1964). The soil samples were amended with 2,3,5-triphenyltetrazolium chloride (TTC) and incubated for $24 \mathrm{~h}$ at $37{ }^{\circ} \mathrm{C}$. TTC was reduced to triphenyl formazan (TPF) which was extracted from the reaction mixture with methanol and assayed colorimetrically with Beckman DU600 ${ }^{\oplus}$ spectrophotometer (Beckman Coulter Inc., Brea, (A, USA) at a wavelength of $450 \mathrm{~nm}$ (Casida et al. 1964).

\section{Statistical analysis}

Means and standard deviations were computed to present general characteristics of the soil properties. Analysis of variance was applied to determine the significance of differences between mean values of soil parameters. Prior to the variance analysis, normal distribution of variables was tested using the Shapiro-Wilk test, and homogeneity of variance using the Levene's test.

Due to departures from normal distribution, non-parametric Kruskal-Wallis test was conducted for all studied variables. The relationship between physico-chemical and biological properties of soils as well as the impact of afforestation on properties of grassland soils was assessed using the Spearman's correlation rank analysis for both linear and non-linear dependencies. Principal component analysis (PCA) was performed to indicate the main soil parameters which affect the principal components.

The soil quality index (SQI) value was calculated in order to integrate physico-chemical and biological parameters into a single numerical value. According to Bastida et al. (2008) it is advisable to evaluate the soil quality by combining different soil parameters. Only the variables with high load factor on the main PC components were taken into consideration for SQI calculation. High load factor was defined as an absolute value within $10 \%$ of the highest value of the load factor (Andrews et al. 2002). With the use of PCA, the soil quality index was determined in order to compare the soils of different forest stands and meadows. SQI was calculated according to Sinha et al. (2009) as follows (eqn. 2):

$$
S Q I=\sum_{i=1}^{n} W_{i} S_{i}
$$

where $W$ is the weighting factor of soil properties selected from the results of the PCA analysis within a given PC component, and $\mathrm{S}$ refers to their respective scores.

To convert real values of individual soil properties into a score ( $S$ ), an equation defined as the sigmoid curve (which has an asymptote to 1 and to 0 ) was applied (eqn. 3):

$$
S=\frac{a}{1+\left(\frac{x}{x_{o}}\right)^{b}}
$$

where $x$ is the value of the soil property, $a$ reflects the maximum value $(a=1.00), x_{0}$ is the mean value of each soil parameter, and $b$ is the equation slope.

A slope in the curve of -2.5 means "more is the better" whereas a slope of +2.5 denotes "less is the better". In this way, we obtained a sigmoid curve at 1 for all suggested properties. According to many authors (Amacher et al. 2007, Bastida et al. 2008, Das et al. 2016) synthetic indices of soil quality are useful tools that can be used to monitor changes in soil quality and to establish a reference point for different soil management practices. Higher values of soil quality indices mean higher soil quality (Moran et al. 2000, Lu et al. 2002, Sinha et al. 2009).

Statistical analyses were conducted using the software STATISTICA ${ }^{\oplus}$ ver. 12.0 (StatSoft Inc., Tulsa, OK, USA). Graphs were produced using the package MS Excel $^{\circledR}$ (Microsoft Inc., Redmond, WA, USA).

\section{Results}

\section{Physical, physico-chemical and} biological properties of soils

All examined soils were classified as sandy soils (WRB 2015). The content of the sand fraction (2-0.05 mm) was greater than

Tab. 3 - Physico-chemical and biological properties (mean \pm standard deviation) in layers 0-10 cm and 10-30 cm of differently used soils. Different letters indicate significant $(\mathrm{p}<0.05)$ differences between mean values. $(\mathrm{H}: \mathrm{F})$ : ratio of humic acid carbon to fulvic acid carbon; (Hd): degree of humification [\%]; ( $\left.\mathrm{C}_{\text {org }}\right)$ : organic carbon [ $\left.\mathrm{g} \mathrm{kg}^{-1}\right] ;\left(\mathrm{N}_{\mathrm{tot}}\right)$ : total nitrogen [ $\left.\mathrm{g} \mathrm{kg}^{-1}\right]$; $(\mathrm{C} / \mathrm{N})$ : ratio of organic carbon to total nitrogen; (DHA): dehydrogenase activity $\left[\mathrm{cm}^{3} \mathrm{H}_{2} \mathrm{~kg}^{-1} \mathrm{~d}^{-1}\right] ;\left(\mathrm{P}_{\mathrm{av}}\right)$ : available $\mathrm{P}\left[\mathrm{mg} \mathrm{kg}^{-1}\right]$; $\left(\mathrm{K}_{\mathrm{av}}\right)$ : available $\mathrm{K}\left[\mathrm{mg} \mathrm{kg}^{-1}\right]$; $\left(\mathrm{Mg}_{\mathrm{av}}\right)$ : available

\begin{tabular}{|c|c|c|c|c|c|c|c|}
\hline \multirow{2}{*}{ Layer } & \multirow{2}{*}{ Property } & \multicolumn{2}{|c|}{ Borek Falecki (area 1) } & \multicolumn{2}{|c|}{ Skalki Twardowskiego (area 2) } & \multicolumn{2}{|c|}{ Skotniki (area 3) } \\
\hline & & Grassland G1 & Forest F1 & Grassland G2 & Forest F2 & Grassland G3 & Forest F3 \\
\hline \multirow[t]{8}{*}{$0-10 \mathrm{~cm}$} & $\mathrm{H}: \mathrm{F}$ & $0.71 \pm 0.06^{a}$ & $0.48 \pm 0.02^{b}$ & $2.05 \pm 0.18^{a}$ & $0.50 \pm 0.05^{b}$ & $1.27 \pm 0.10^{a}$ & $0.65 \pm 0.04^{b}$ \\
\hline & $\mathrm{Hd}$ & $42.01 \pm 3.40^{a}$ & $27.95 \pm 0.95^{b}$ & $55.98 \pm 0.92^{a}$ & $28.18 \pm 2.68^{b}$ & $43.85 \pm 3.35^{a}$ & $39.84 \pm 1.33^{\mathrm{a}}$ \\
\hline & $\mathrm{C}_{\text {org }}$ & $18.71 \pm 2.55^{a}$ & $44.00 \pm 0.90^{b}$ & $11.01 \pm 2.44^{\mathrm{a}}$ & $13.92 \pm 3.58^{b}$ & $26.29 \pm 3.34^{\mathrm{a}}$ & $33.95 \pm 0.97^{b}$ \\
\hline & $\mathrm{N}_{\text {tot }}$ & $1.77 \pm 0.11^{a}$ & $2.86 \pm 0.10^{b}$ & $1.10 \pm 0.09^{a}$ & $1.33 \pm 0.29^{a}$ & $2.39 \pm 0.09^{a}$ & $2.78 \pm 0.12^{b}$ \\
\hline & $\mathrm{C} / \mathrm{N}$ & $10.65 \pm 1.81^{a}$ & $15.39 \pm 0.38^{b}$ & $9.95 \pm 1.80^{\mathrm{a}}$ & $10.59 \pm 2.07^{a}$ & $10.99 \pm 1.08^{a}$ & $12.21 \pm 0.31^{\mathrm{a}}$ \\
\hline & $\mathrm{P}_{\mathrm{av}}$ & $2.77 \pm 0.13^{a}$ & $4.98 \pm 0.33^{b}$ & $43.49 \pm 1.91^{\mathrm{a}}$ & $50.87 \pm 3.35^{b}$ & $3.97 \pm 0.17^{\mathrm{a}}$ & $2.70 \pm 0.12^{b}$ \\
\hline & $\mathrm{K}_{\mathrm{av}}$ & $6.44 \pm 0.25^{a}$ & $3.15 \pm 0.10^{b}$ & $2.38 \pm 0.09^{a}$ & $3.45 \pm 0.15^{b}$ & $3.09 \pm 0.09^{a}$ & $4.01 \pm 0.12^{b}$ \\
\hline & $\mathrm{Mg}_{\mathrm{av}}$ & $28.10 \pm 0.61^{a}$ & $25.78 \pm 1.18^{b}$ & $33.23 \pm 0.87^{a}$ & $14.19 \pm 0.38^{b}$ & $13.64 \pm 0.58^{a}$ & $1.10 \pm 0.09^{b}$ \\
\hline \multirow[t]{8}{*}{$10-30 \mathrm{~cm}$} & $\mathrm{H}: \mathrm{F}$ & $0.89 \pm 0.05^{a}$ & $0.66 \pm 0.03^{b}$ & $2.17 \pm 0.15^{a}$ & $0.53 \pm 0.04^{b}$ & $1.35 \pm 0.07^{a}$ & $0.69 \pm 0.04^{b}$ \\
\hline & $\mathrm{Hd}$ & $52.70 \pm 2.80^{a}$ & $38.33 \pm 2.60^{b}$ & $64.58 \pm 1.72^{a}$ & $47.30 \pm 0.78^{b}$ & $49.69 \pm 3.50^{a}$ & $44.27 \pm 3.34^{b}$ \\
\hline & $C_{\text {org }}$ & $16.78 \pm 1.02^{a}$ & $15.33 \pm 2.10^{a}$ & $4.95 \pm 0.47^{a}$ & $2.99 \pm 0.89^{b}$ & $19.73 \pm 4.27^{a}$ & $18.58 \pm 0.81^{a}$ \\
\hline & $\mathrm{N}_{\text {tot }}$ & $1.50 \pm 0.02^{a}$ & $1.31 \pm 0.19^{a}$ & $0.92 \pm 0.14^{\mathrm{a}}$ & $0.63 \pm 0.20^{b}$ & $1.80 \pm 0.46^{a}$ & $1.73 \pm 0.04^{a}$ \\
\hline & $\mathrm{DHA}$ & $0.48 \pm 0.03^{a}$ & $0.34 \pm 0.06^{b}$ & $0.35 \pm 0.11^{a}$ & $0.23 \pm 0.03^{a}$ & $0.65 \pm 0.09^{a}$ & $0.41 \pm 0.07^{b}$ \\
\hline & $\mathrm{P}_{\mathrm{av}}$ & $3.04 \pm 0.12^{a}$ & $3.85 \pm 0.12^{b}$ & $40.72 \pm 12.2^{a}$ & $47.19 \pm 2.34^{a}$ & $6.66 \pm 0.30^{a}$ & $2.57 \pm 0.05^{b}$ \\
\hline & $\mathrm{K}_{\mathrm{av}}$ & $4.14 \pm 0.10^{a}$ & $3.24 \pm 0.14^{b}$ & $2.10 \pm 0.05^{a}$ & $1.72 \pm 0.08^{b}$ & $2.18 \pm 0.03^{a}$ & $2.10 \pm 0.28^{a}$ \\
\hline & $\mathrm{Mg}_{\mathrm{av}}$ & $24.60 \pm 0.64^{a}$ & $19.54 \pm 0.58^{b}$ & $14.75 \pm 0.42^{a}$ & $1.26 \pm 0.17^{b}$ & $11.05 \pm 0.54^{a}$ & $0.93 \pm 0.07^{b}$ \\
\hline
\end{tabular}
$\mathrm{Mg}\left[\mathrm{mg} \mathrm{kg}^{-1}\right]$. 
$85 \%$ (Tab. 2).

A higher content of $\mathrm{C}_{\text {org }}$ and $\mathrm{N}_{\text {tot }}$ was observed in the topsoil of forest stands compared to grassland soils, while in subsoils an inverse relationship was observed. The mean contents of these elements in the 0 $10 \mathrm{~cm}$ layer were $30.61 \mathrm{~g} \mathrm{C}_{\text {org }} \mathrm{kg}^{-1}$ and $2.32 \mathrm{~g}$ $\mathrm{N}_{\text {tot }} \mathrm{kg}^{-1}$ in soils $\mathrm{F} 1-\mathrm{F} 3$, and $18.67 \mathrm{~g} \mathrm{Corg} \mathrm{kg}^{-1}$ and $1.75 \mathrm{~g} \mathrm{~N}_{\text {tot }} \mathrm{kg}^{-1}$ in soils $\mathrm{G}_{1}-\mathrm{G}_{3}$ (Tab. 3). In subsoils, the values were $12.3 \mathrm{~g} \mathrm{Corg} \mathrm{kg}^{-1}$ and $1.22 \mathrm{~g} \mathrm{~N}_{\text {tot }} \mathrm{kg}^{-1}$ in soils of forest stands and $13.82 \mathrm{~g} \mathrm{C}_{\text {org }} \mathrm{kg}^{-1}$ and $1.40 \mathrm{~g} \mathrm{~N}_{\text {tot }} \mathrm{kg}^{-1}$ in grassland soils (Tab. 3). The highest increase in $C_{\text {org }}$ content, nearly $150 \%$, was noticed in $\mathrm{F} 1$ soils, which may be due to the large share of Pinus sylvestris in the forest stand. In soils of the remaining forest stands, $\mathrm{F} 2$ and $\mathrm{F} 3$, these changes amounted to 30\% (Fig. $3)$. In the subsoil, a reduction of approximately $11 \%, 40 \%$ and $10 \%$ occurred in the content of this element in soils $\mathrm{F}_{1}, \mathrm{~F}_{2}$ and $F_{3}$, respectively, as compared to soils $G_{1}$, $\mathrm{G}_{2}$ and $\mathrm{G}_{3}$ (Fig. 4). It should be noted that changes equal or smaller than $11 \%$ were statistically non-significant (Tab. 3). The ratio $\mathrm{C} / \mathrm{N}$ in $\mathrm{F} 1-\mathrm{F} 3$ soils in the individual layers was in the range of 10.59-15.39 in top layers and 4.87-11.72 in the $10-30 \mathrm{~cm}$ layers, while in the grassland soils it was in the range 9.9510.99 and 5.44-12.03, respectively.

The composition of soil organic matter (SOM) was described by two parameters: the ratio of humic acids carbon to fulvic acids carbon (H:F) and the degree of humification ( $\mathrm{Hd}$ ). Higher values of both parameters were observed in both designated layers in grassland soils, compared to forest soils in each of the three stands. In grassland soils mean $\mathrm{H}: \mathrm{F}$ was 1.34 and 1.47 in $0-10 \mathrm{~cm}$ and $10-30 \mathrm{~cm}$ layers, respectively, while in forest soils $\mathrm{H}: \mathrm{F}$ was 0.54 and 0.63 in $0-10 \mathrm{~cm}$ and $10-30 \mathrm{~cm}$ layers, respectively. $\mathrm{Hd}$ in top layers of grassland and forest soils was $47.3 \%$ and $32.0 \%$, respectively, while in $10-30 \mathrm{~cm}$ layers $\mathrm{Hd}$ amounted to $55.7 \%$ and $43.3 \%$ (Tab. 3). In both layers, H:F changes in the compared soils were similar (Fig. 3 and Fig. 4). The lowest changes in $\mathrm{Hd}$ occurred in $\mathrm{F}_{3}$ as compared to $\mathrm{G}_{3}$ (about 10\%), as shown in Fig. 3 and Fig. 4.

The mean values of $\mathrm{pH}_{1 \mathrm{M}-\mathrm{Kcl}}$ were always higher in grassland soils (G1-G3) compared to forest soils (F1-F3) and these values slightly increased with depth (less than 0.5 units). The direction of change in $\mathrm{pH}$ in the compared grassland and forest soils was the same in both layers, which means that $\mathrm{pH}$ decreases in forest soils compared to grassland soils. The biggest changes were observed in soils of F1 (approximately 30\% in both layers), while in the soils of $\mathrm{F} 2$ and $\mathrm{F}_{3}$, the changes amounted to about $20 \%$ (Fig. 3 and Fig. 4). The strongest acidification in relation to reference grassland soils was recorded in F1 soils, where coniferous trees grow, whereas the smallest acidification was noted in $F_{3}$ soils (deciduous trees). Mean total acidity ( $\mathrm{Hh}$ ) values for $\mathrm{F} 1$ were 18 and 17 times higher in the $0-10 \mathrm{~cm}$ and $10-30 \mathrm{~cm}$ layers, respectively. Similarly, for F2, the values were 15 and 9 times

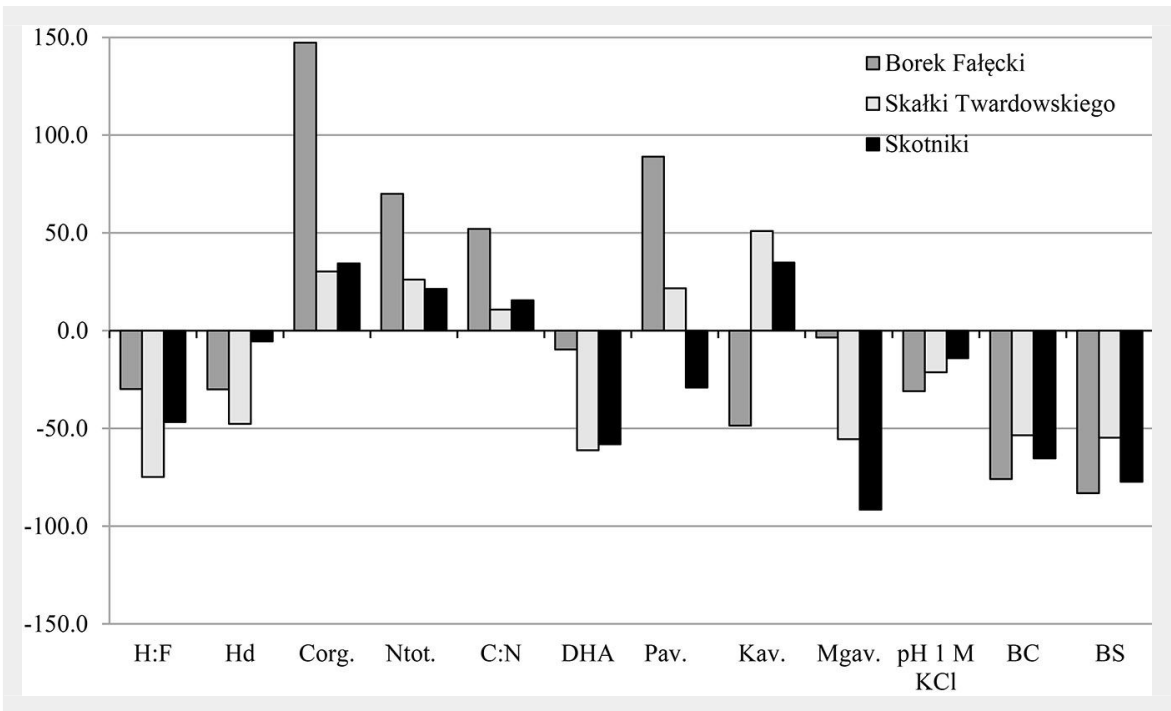

Fig. 3 - Differences in grassland soils properties after afforestation in the $0-10 \mathrm{~cm}$ layer expressed in \%.

higher, and for $\mathrm{F}_{3}$ the values where 9 and 4 times higher, in the in $0-10 \mathrm{~cm}$ and $10-30 \mathrm{~cm}$ layers, respectively. Such large changes in mean $\mathrm{Hh}$ values indicate that the trees introduced during the process of afforestation of grassland soils triggered an intensive process of acidification, and that this process was less advanced in subsoils. Acidification can be seen in the sorption complex, which is manifested by the leaching of alkaline components and reduction by approximately $55-80 \%$ in BS of forest soils in relation to grassland soils (Fig. 3 and Fig. 4).

A significant variability in the content of available $\mathrm{P}_{\mathrm{av}}, \mathrm{K}_{\mathrm{av}}$ and $\mathrm{Mg}_{\mathrm{av}}$ contents, both between the designated layers and soils under different uses, as well as between different areas, were found. The highest mean contents of $P_{a v}$, over $40 \mathrm{mg} \mathrm{kg}^{-1}$ in both studied layers, were observed in $\mathrm{G}_{2}$

and F2. In the studied layers of the remaining soils the mean content of this element did not exceed $7 \mathrm{mg} \mathrm{kg}^{-1}$. The high accumulation of available phosphorus in differently used soils of $\mathrm{G}_{2}$ and $\mathrm{F}_{2}$ may be the result of being "washed in" from adjacent horsts of carbonate rocks, which are rich in $\mathrm{P}_{2} \mathrm{O}_{5}$. In forest soils ( $\mathrm{F} 1$ and $\mathrm{F}_{2}$ ) there were higher mean contents of available $P$ than in reference grassland soils ( $G_{1}$ and $G_{2}$ ), while in $\mathrm{G}_{3}$ soil the content of $\mathrm{P}_{\mathrm{av}}$ was higher than in F3 soil. In the soils of the examined areas, the mean contents of $\mathrm{K}_{\mathrm{av}}$ and $\mathrm{Mg}_{\mathrm{av}}$ were usually higher in grassland soils than in the corresponding forest soils (Tab. 3).

Mean values of the activity of dehydrogenase (DHA) were lower in forest soils than in grassland soils. In F1-F3 soils, in the topsoil and subsoil, values ranged between 0.69 and 0.91 , and between 0.23 and 0.41 $\mathrm{cm}^{3} \mathrm{H}_{2} \mathrm{~kg}^{-1} \mathrm{~d}^{-1}$ respectively; in $\mathrm{G}_{1}-\mathrm{G}_{3}$ soils,

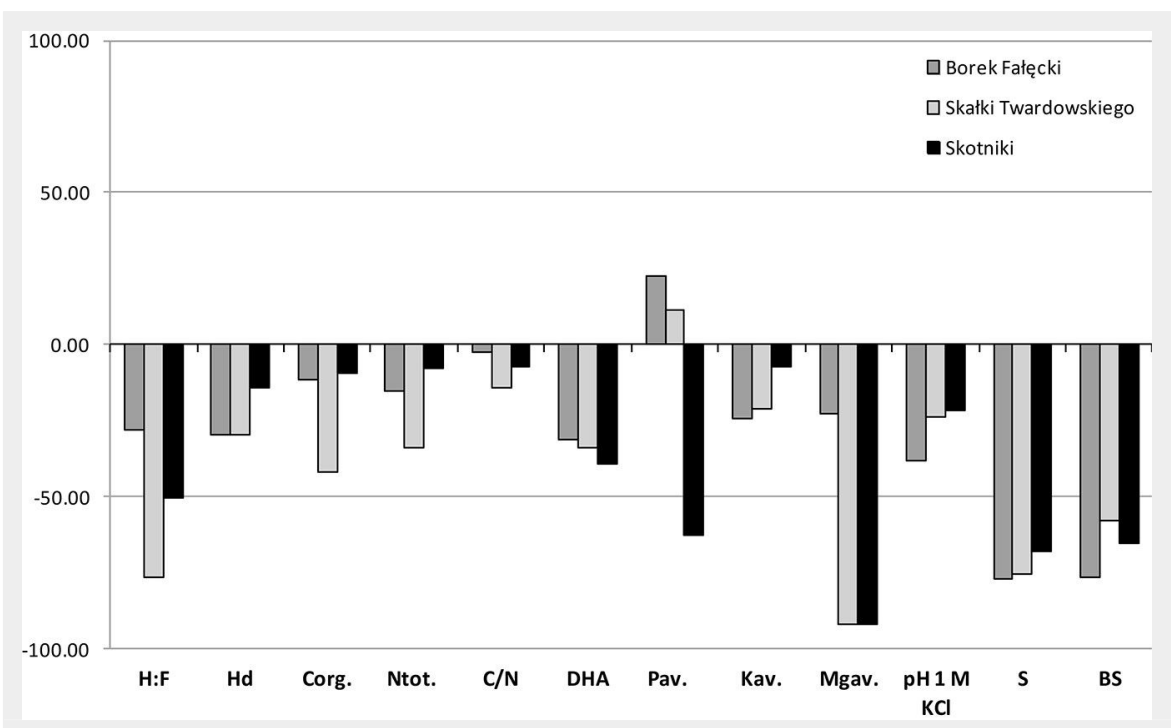

Fig. 4 - Differences in grassland soils properties after afforestation in the $10-30 \mathrm{~cm}$ layer expressed in \%. 
Tab. 4 - Results of principal component analysis of soil parameters $(n=168) . S Q I=0.415 \mathrm{Hd}+0.415 \mathrm{C}_{\mathrm{org}}+0.415 \mathrm{Hh}+0.255 \mathrm{Mg} \mathrm{S}^{2+}+0.255$ $\mathrm{P}_{\mathrm{av}}+0.101 \mathrm{~K}_{\mathrm{av}}+0.083 \mathrm{DHA}+0.083 \mathrm{Mg}_{\mathrm{av}}$. Normalized SQI $=\mathrm{SQI} / 2.022$. Final SQI $=0.205 \mathrm{Hd}+0.205 \mathrm{C}_{\mathrm{org}}+0.205 \mathrm{Hh}+0.126 \mathrm{Mg}^{2+}+0.126 \mathrm{P}_{\mathrm{av}}+$ $0.05 \mathrm{~K}_{\mathrm{av}}+0.041 \mathrm{DHA}+0.041 \mathrm{Mg}_{\mathrm{av}}$. For grassland soil "more is better" thus -2.5 for Hd, $\mathrm{C}_{\text {org }}, \mathrm{P}_{\mathrm{av}}, \mathrm{Mg}^{2+}, \mathrm{K}_{\mathrm{av}}, \mathrm{Mg}_{\mathrm{av}}$, DHA and "less is better" thus +2.5 for Hh and for forest soil Hh also included "more is better" thus -2.5 .

\begin{tabular}{|c|c|c|c|c|}
\hline Principal components & PC1 & PC2 & PC3 & PC4 \\
\hline Variation (\%) & 41.59 & 25.59 & 10.13 & 8.38 \\
\hline Cumulative variation (\%) & 41.59 & 67.18 & 77.31 & 85.70 \\
\hline $\mathrm{H}: \mathrm{F}$ & 0.703 & -0.171 & 0.565 & 0.010 \\
\hline $\mathrm{Hd}$ & $0.797^{\mathrm{a}}$ & -0.053 & 0.270 & 0.389 \\
\hline $\mathrm{C}_{\text {org }}$ & $-0.779^{a}$ & -0.535 & 0.171 & -0.119 \\
\hline $\mathrm{N}_{\text {tot }}$ & -0.703 & -0.575 & 0.246 & -0.019 \\
\hline $\mathrm{C} / \mathrm{N}$ & -0.636 & -0.515 & -0.036 & -0.249 \\
\hline DHA & 0.072 & -0.442 & 0.513 & $-0.564^{a}$ \\
\hline $\mathrm{pH}_{1 \mathrm{M} \mathrm{KCl}}$ & 0.866 & -0.317 & -0.245 & -0.029 \\
\hline $\mathrm{Hh}$ & $-0.944^{\mathrm{a}}$ & 0.139 & 0.009 & 0.114 \\
\hline $\mathrm{Ca}^{2+}$ & 0.750 & -0.535 & 0.323 & 0.028 \\
\hline $\mathrm{Mg}^{2+}$ & 0.296 & $-0.642^{a}$ & -0.508 & -0.108 \\
\hline $\mathrm{K}^{+}$ & 0.016 & -0.617 & -0.380 & 0.487 \\
\hline $\mathrm{Na}^{+}$ & 0.015 & -0.651 & 0.103 & 0.487 \\
\hline $\mathrm{BC}$ & 0.736 & -0.593 & 0.219 & 0.023 \\
\hline BS & 0.882 & -0.393 & 0.113 & -0.069 \\
\hline $\mathrm{P}_{\mathrm{av}}$ & 0.450 & $0.693^{a}$ & 0.079 & -0.331 \\
\hline $\mathrm{K}_{\mathrm{av}}$ & -0.100 & -0.604 & $-0.654^{a}$ & -0.199 \\
\hline $\mathrm{Mg}_{\mathrm{av}}$ & 0.306 & -0.452 & -0.192 & $-0.644^{a}$ \\
\hline
\end{tabular}

F1-F3 forest soils, G1-G3 grassland soils

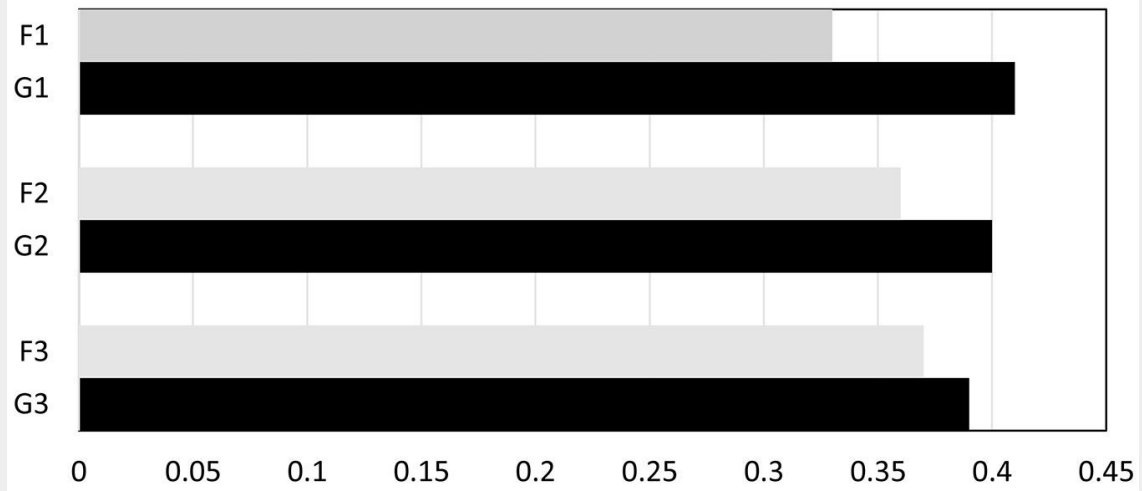

Fig. 5 - Soil quality index values (SQI) of grassland and forest soils.
DHA activity in analogous layers ranged from 0.97 to 2.25 and from 0.35 to $0.65 \mathrm{~cm}^{3}$ $\mathrm{H}_{2} \mathrm{~kg}^{-1} \mathrm{~d}^{-1}$ (Tab. 3).

Soil quality index (SQI)

Tab. 4 reports the eigenvalues obtained from PCA in descending order, thus representing the importance of relevant factors in explaining the total variability of the data. The analysis showed that the first factor (PC1), which corresponded to the highest eigenvalue of 8.3, accounted for about $41.6 \%$ of the total variation, whereas the other values, $\mathrm{PC}_{2}, \mathrm{PC}_{3}$ and $\mathrm{PC}_{4}$, which corresponded respectively to eigenvalues 5.12 , 2.03 and 1.68 , accounted for $25.6 \%, 10.1 \%$

Tab. 5 - Coefficients of Spearman's rank correlation between soil parameters in forest soils. $(*): p<0.05 ;(* *): p<0.01 ;(* * *): p<0.001$.

\begin{tabular}{|c|c|c|c|c|c|c|c|c|c|c|c|c|c|c|c|c|c|}
\hline- & $\mathrm{H}: \mathrm{F}$ & $\mathrm{Hd}$ & $\mathrm{C}_{\text {org }}$ & $\mathbf{N}_{\text {tot }}$ & $\mathrm{C} / \mathrm{N}$ & DHA & $\mathrm{pH}$ & $\mathrm{Hh}$ & $\mathrm{Mg}^{2+}$ & $\mathrm{Ca}^{2+}$ & $\mathrm{K}^{+}$ & $\mathrm{Na}^{+}$ & $B C$ & BS & $P_{a v}$ & $\mathrm{~K}_{\mathrm{av}}$ & $\mathrm{Mg}_{\mathrm{av}}$ \\
\hline $\mathrm{H}: \mathrm{F}$ & 1.00 & - & - & - & - & - & - & - & - & - & - & - & - & - & - & - & - \\
\hline $\mathrm{Hd}$ & $0.79^{* * *}$ & 1.00 & - & - & - & - & - & - & - & - & - & - & - & - & - & - & - \\
\hline$C_{\text {org }}$ & $-0.37^{*}$ & $-0.57^{* *}$ & 1.00 & - & - & - & - & - & - & - & - & - & - & - & - & - & - \\
\hline $\mathrm{N}_{\text {tot }}$ & $-0.30^{*}$ & $-0.48^{*}$ & $0.95^{* * *}$ & * 1.00 & - & - & - & - & - & - & - & - & - & - & - & - & - \\
\hline $\mathrm{C} / \mathrm{N}$ & $-0.35^{*}$ & $-0.56^{* *}$ & $0.80^{* * *}$ & ${ }^{*} 0.63^{* *}$ & 1.00 & - & - & - & - & - & - & - & - & - & - & - & - \\
\hline DHA & $0.35^{*}$ & $0.01^{*}$ & $0.29^{*}$ & $0.37^{*}$ & $0.19^{*}$ & 1.00 & - & - & - & - & - & - & - & - & - & - & - \\
\hline $\mathrm{pH}$ & $0.55^{* *}$ & $0.69^{* *}$ & -0.49 & $-0.46^{*}$ & $0.37^{*}$ & $0.05^{*}$ & 1.00 & - & - & - & - & - & - & - & - & - & - \\
\hline $\mathrm{Hh}$ & $-0.59^{* *}$ & $-0.66^{* *}$ & $0.67^{* *}$ & $0.60^{* *}$ & $0.48^{*}$ & $-0.20^{*}$ & $-0.82^{* * *}$ & 1.00 & - & - & - & - & - & - & - & - & - \\
\hline $\mathrm{Mg}^{2+}$ & $0.01^{*}$ & $0.06^{*}$ & $0.01^{*}$ & $0.07^{*}$ & $0.12^{*}$ & $0.15^{*}$ & $0.50^{*}$ & $-0.39^{*}$ & 1.00 & - & - & - & - & - & - & - & - \\
\hline $\mathrm{Ca}^{2+}$ & $0.74^{* *}$ & $0.66^{* *}$ & $-0.24^{*}$ & $-0.12^{*}$ & $-0.22^{*}$ & $0.41^{*}$ & $0.72^{* *}$ & $-0.80^{* * *}$ & ${ }^{*} 0.42^{*}$ & 1.00 & - & - & - & - & - & - & - \\
\hline $\mathrm{K}^{+}$ & $-0.01^{*}$ & $0.21^{*}$ & $0.24^{*}$ & $0.28^{*}$ & $0.17^{*}$ & $-0.17^{*}$ & $0.38^{*}$ & $0.05^{*}$ & $0.46^{*}$ & $0.17^{*}$ & 1.00 & - & - & - & - & - & - \\
\hline $\mathrm{Na}^{+}$ & $0.13^{*}$ & $0.20^{*}$ & $0.28^{*}$ & $0.38^{*}$ & $0.32^{*}$ & $0.12^{*}$ & $0.12^{*}$ & $-0.12^{*}$ & $0.37^{*}$ & $0.47^{*}$ & $0.50^{*}$ & 1.00 & - & - & - & - & - \\
\hline$B C$ & $0.69^{* *}$ & $0.62^{* *}$ & $-0.22^{*}$ & $-0.09^{*}$ & $-0.19^{*}$ & $0.40^{*}$ & $0.74^{* *}$ & $-0.79^{* * *}$ & $0.54^{*}$ & $0.99^{* * *}$ & $0.25^{*}$ & $0.50^{* *}$ & 1.00 & - & - & - & - \\
\hline BS & $0.71^{* *}$ & $0.70^{* *}$ & $-0.42^{*}$ & $-0.32^{*}$ & $-0.33^{*}$ & $0.35^{*}$ & $0.87^{* * *}$ & $-0.91^{* * *}$ & * $0.50^{*}$ & $0.95^{* * *}$ & $0.19^{*}$ & $0.31^{*}$ & $0.95^{* * *}$ & 1.00 & - & - & - \\
\hline $\mathrm{P}_{\mathrm{av}}$ & $0.31^{*}$ & $0.21^{*}$ & $-0.64^{* *}$ & $-0.65^{* *}$ & $-0.63^{* *}$ & $-0.08^{*}$ & $0.20^{*}$ & $-0.30^{*}$ & -0.29 & $-0.01^{*}$ & $-0.51^{* *}$ & $-0.77^{* * *}$ & $-0.06^{*}$ & $0.13^{*}$ & 1.00 & - & - \\
\hline $\mathrm{K}_{\mathrm{av}}$ & $-0.34^{*}$ & $-0.30^{*}$ & $0.31^{*}$ & $0.32^{*}$ & $0.37^{*}$ & $0.14^{*}$ & $0.26^{*}$ & $0.01^{*}$ & $0.74^{* *}$ & $0.05^{*}$ & $0.53^{* *}$ & $0.30^{*}$ & $0.16^{*}$ & $0.12^{*}$ & $-0.42^{*}$ & 1.00 & - \\
\hline $\mathrm{Mg}_{\mathrm{av}}$ & $0.30^{*}$ & $0.05^{*}$ & $0.07^{*}$ & $-0.04^{*}$ & $0.30^{*}$ & $0.35^{*}$ & $-0.54^{* *}$ & $-0.36^{*}$ & $0.42^{*}$ & $0.33^{*}$ & $0.12^{*}$ & $-0.01^{*}$ & $0.37^{*}$ & $0.44^{*}$ & $-0.01^{*}$ & $0.42^{*}$ & 1.00 \\
\hline
\end{tabular}


and $8.4 \%$ of the total variation. Four factors exceeded the eigenvalue 1 , accounting for approximately $85.7 \%$ of the total variation, and therefore, these were selected for the analysis. Among the variables which were highly correlated $(r>0.7)$, the variable with the highest correlation factor was chosen for the SQI calculation. Finally, PCA was used to select the following variables: Hh, $\mathrm{Hd}, \mathrm{C}_{\text {org }}, \mathrm{Mg}^{2+}, \mathrm{P}_{\mathrm{av}}, \mathrm{K}_{\mathrm{av}}, \mathrm{Mg}_{\mathrm{av}}$ and DHA, which were taken into consideration during the synthetic evaluation of the quality of examined soils.

When comparing values of SQI of differently used soils, lower values were found in forest stand soils compared to grassland soils in all the studied stands. The values of SQI were as follows: $\mathrm{G}_{1} 0.41$ and $\mathrm{F}_{1} \mathrm{0.33}$; $\mathrm{G}_{2}$ 0.40 and $F_{2} \quad 0.36 ; G_{3} 0.39$ and $F_{3} 0.37$ (Fig. 5). The differences were $24 \%, 11 \%$ and $4 \%$, respectively. Between soils of different forest stands, the differences in SQI did not exceed $10 \%$.

\section{Discussion}

\section{The impact of afforestation on the physico-chemical and biological properties of grassland soils}

We ascertained that the highest carbon accumulation occurs in forest stands composed of deciduous tree species with an admixture of coniferous species. This observation was explained by Andivia et al. (2016) by a complementarity between these tree species. Coniferous trees provide the soils with organic carbon mainly by root turnover, while deciduous trees by the fall of leaves. Conifers usually have shallow rooting systems and therefore they accumulate more organic carbon in top soil layers than deciduous trees, which have a deeper rooting system (Schulp et al. 2008, Vesterdal et al. 2008). Moreover, the accumulation of $C_{\text {org }}$ increases with the age of the forest and the dynamics of this modification decreases with the depth of soil, as observed by Farley \& Kelly (2004), Smal \& Olszewska (2008) and Orczewska et al. (2012). The changes in $\mathrm{N}_{\text {tot }}$ content, observed in both designated layers, were similar to the changes in $\mathrm{C}_{\text {org }}$. Contrary to our expectations, we did not detect any increase in nitrogen accumulation in stands dominated by alder. These results are consistent with findings of Miletić et al. (2012), who also did not find any increase in $\mathrm{N}$ content in stands with alder. According to their study, species growing in the vicinity of alder use the nitrogen accumulated by this species.

Organic matter (in the form of fallen leaves, twigs, etc.) in the differently used soils (grassland $\mathrm{G}_{1}-\mathrm{G}_{3}$, and forest $\mathrm{F}_{1}-\mathrm{F}_{3}$ ) is decomposed at different rates in the studied layers. It can be deduced from the $\mathrm{C} / \mathrm{N}$ ratio (Tab. 3) that mineralization and humification processes of organic matter, are faster in topsoils of grasslands than in the corresponding layers of forest soils, which is consistent with previous studies (Ross et al. 1999, Griffiths et al. 2005, Gonet et al. 2009, Holubík et al. 2014). This relationship is expressed by a high negative correlation coefficient between $\mathrm{C} / \mathrm{N}$ and $\mathrm{Hd}(\mathrm{r}=-0.56$, $\mathrm{p}<0.01$ - Tab. 5).

In shaping the quantity and properties of SOM, a fundamental role is played by the properties of litter as a substrate of the humification process, as well as by habitat conditions (climate, physico-chemical soil properties) in which the decomposition takes place (Gonet et al. 2009, Miletić et al. 2012, Jonczak 2013, Maly et al. 2014). Based on our results, a lower humification rate of SOM and a lower H:F value were ascertained in afforested soils compared with grassland soils (Tab. 3). This indicates that the changes in SOM lead to forest humus formation which is characterised by lower $\mathrm{Hd}$ and narrower $\mathrm{H}: \mathrm{F}$ than in grassland soils. These results are consistent with those obtained by Smal et al. (2004), Gonet et al. (2009) as well as Jonczak (2013), whose research confirms the significant impact of the land use (grassland or forest) on the properties of organic matter.

An important factor contributing to the impoverishment of cations in forest soils is the higher biomass production compared to grassland soils. A large proportion of the cations needed for biomass production are fixed in the wood and bark of trunks, as well as roots, branches and leaves. Those cations return to the soils after a much longer cycle compared to grassland soils (Jobbágy \& Jackson 2003). The acidic products of humus decomposition initiate subsequent processes of change, of which the acidification and leaching of cations is the most important. The natural process of soil acidification is inherently connected with the decomposition of organic matter and the absorption of nutrients. These processes are particularly intensive in forest soils (Uri et al. 2011). Relationships between these parameters are expressed by a positive correlation coefficient between $\mathrm{pH}$ and $\mathrm{H}: \mathrm{F}(\mathrm{r}=0.55, \mathrm{p}<0.01)$, as well as between $\mathrm{pH}$ and $\mathrm{BS}(\mathrm{r}=0.71, \mathrm{p}<0.01-$ Tab. 5).

DHA was lower in forest stand soils than in grassland soils, and this was probably the result of forest soil acidification. The optimal values of $\mathrm{pH}$ for DHA, ranges from 6.3-7.2, while the mean $\mathrm{pH}$ value in the studied forest soils was 3.9. According to Blonska \& Januszek (2010, Blonska \& Januszek 2013, Blonska et al. 2017), soil reaction among the properties which most influences DHA activity.

Changes in the mean content of the available studied elements varied considerably between differently used soils for all the examined sites. In general, the content of $K_{a v}$ and $P_{a v}$ increased in topsoils of forests, in comparison to corresponding grassland soils. However, the observed changes were not always statistically significant (Tab. 3). Similar relationships, or the lack of a clear enrichment in $\mathrm{P}_{\mathrm{av}}$ as the forest age increases, are reported by Orczewska et al.
(2012), who evaluated the content of this element in soils covered by Alnus glutinosa. According to Alban (1981), the content of available forms of $P$ and $K$ in soils of forest habitats depends on the dominance of a particular tree species. He observed higher contents of these components in soils covered with deciduous trees (poplar) than in soils under coniferous species (pine).

\section{Evaluation of soil quality (SQI)}

In this study we assumed that the differences in properties and SQI values between grassland and afforested soils resulted mainly from the influence of different tree species, modified by the time passed since afforestation.

A slightly higher SQI observed in $\mathrm{F}_{3}$, as compared to the remaining forest soils, may have resulted from the dominance of the black alder $(80 \%)$ in the species composition. The period of influence of the introduced forest on soils of this area was the shortest (45 years), which suggests that over time, the quality of these forest soils can even improve. SQI in F2 was slightly lower than in F3, probably because of the smaller share of the black alder in this stand. In F2 and F1 stands the share of the black alder was the same (25\%) but SQI was higher in F2 possibly due to the fact that in this stand a more appropriate species composition was present, given the high levels of ground water.

\section{Conclusions}

Afforestation of grassland soils resulted in an increase in $\mathrm{C}_{\text {org }}$ and $\mathrm{N}_{\text {tot }}$ contents but only in the top layers $(0-10 \mathrm{~cm})$. It was estimated that there was also a decrease in $\mathrm{pH}$ which is typical for forest soils. Acidification processes were accompanied by changes in SOM quality, such as lower decomposition rates and lower $\mathrm{H}: \mathrm{F}$ values, as well as a lowering of basic cation levels and DHA activity. SQI indicated that the best species for the afforestation of sandy, humid grassland soils is black alder. With the same share of black alder, higher SQI was calculated for the stand with maples and elm than for the stand with pine, birch and oak. These results may have practical application in further afforestation strategies for humid grassland soils.

\section{References}

Alban DH (1981). Effects of nutrient accumulation by aspen, spruce and pine on soil properties. Soil Science Society of America Journal 46 (4): 853-861. - doi: 10.2136/sssaj1982.036159950 $04600040037 x$

Aleksandrowicz S, Wrochniak-Stopka W (1959). Phosphorite concretions in turonian sediments of Krakow region. Geological Institute 9: 197206. [in Polish]

Amacher MC, O'Neil KP, Perry CH (2007). Soil vital signs: a new Soil Quality Index (SQI) for assessing forest soil health. Research Paper RMRS-RP-65WWW, Rocky Mountain Research Station, USDA Forest Service, Fort Collins, CO, USA, pp. 15. - doi: 10.2737/RMRS-RP-65 
Andivia E, Rolo V, Jonard M, Formánek P, Ponett $\mathrm{Q}$ (2016). Tree species identity mediates mechanisms of top soil carbon sequestration in a Norway spruce and European beech mixed forest. Annals of Forest Science 73: 437-447. - doi: 10.1007/s13595-015-0536-z

Andrews SS, Karlen DL, Mitchell JP (2002). A comparison of soil quality indexing methods for vegetable production systems in Northern California. Agriculture, Ecosystems and Environment 90: 25-45. - doi: 10.1016/S0167-8809 (01)00174-8

Bastida F, Zsolnay A, Hernández T, García C (2008). Past, present and future of soil quality indices: a biological perspective. Geoderma 147: 159-171. - doi: 10.1016/j.geoderma.2008.08.007

Blonska E, Januszek K (2010). The influence of tree species on the enzyme activity and physical-chemical properties of forest soils. Soil Science Annual 61 (2): 5-14. [in Polish]

Blonska E, Januszek K (2013). Usability of enzyme activity in estimation of forest soil quality. Folia Forestalia Polonica 55 (1): 18-26. - doi: 10.2478/ffp-2013-0003

Blonska E, Lasota J, Zwydak M (2017). The relationship between soil properties, enzyme activity and land use. Forest Research Papers 78 (1): 39-44. - doi: 10.1515/frp-2017-0004

Brozek S, Wanic T (2002). Impact of forest litter of Alnus glutinosa (L.) Gaertn., Alnus incana (L.) Moench, Alnus viridis (Chaix) Lam. et DC, Abies alba Mill., and Fagus sylvatica L. on chosen soil properties. Electronic Journal of Polish Agricultural Universities 5 (1): 122-127.

Casida LE, Klein DA, Santoro T (1964). Soil dehydrogenase activity. Soil Science 98: 371-376. doi: 10.1097/00010694-196412000-00004

Ciarkowska K, Solek-Podwika K, Filipek-Mazur B, Tabak M (2017). Comparative effects of lignitederived humic acids and FYM on soil properties and vegetable yield. Geoderma 303: 85-92. org. - doi: 10.1016/j.geoderma.2017.05.022

Claessens H, Oosterbaan A, Savill P, Rondeux J (2010). A review of the characteristics of black alder (Alnus glutinosa (L.) Gaertn.) and their implications for silvicultural practices. Forestry 83 (2): 163-175. - doi: 10.1093/forestry/cppo38

CSO (2014). Report on the forests state in Poland. Environment protection. Statistical information and elaborations. Central Statistical Office, Statistical Publishing Establishment. Warsaw, Poland, pp. 540. [in Polish]

CSO (2015). Environment protection. Statistical information and elaborations. Central Statistical Office, Statistical Publishing Establishment, Warsaw, Poland, pp. 580. [in Polish]

Das B, Chakraborty D, Singh VK, Ahmed M, Singh AK, Barman A (2016). Evaluating fertilization effects on soil physical properties using a soil quality index in an intensive rice-wheat cropping system. Pedosphere 26 (6): 887-894. - doi: 10.1016/S1002-0160(15)60093-5

Duchaufour P, Jacquin F (1966). Nouvelle recherches sur l'extraction etle fractionnement des composes humiques [New research on the extraction and fractionation of humic compounds]. Bulletin ENSA, Nancy, France 8: 1-24. [in French]

Farley KA, Kelly EF (2004). Effects of afforestation of a páramo grassland on soil nutrient status. Forest Ecology and Management 195: 281-
290. - doi: 10.1016/j.foreco.2003.12.015

FPI (2012). Forest protection instruction. General Directorate of the State Forests, Warsaw, Poland, pp. 124.

Giardina CP, Huffman S, Binkley D, Caldwell BA (1995). Alders increase soil phosphorus availability in Douglas-fir plantation. Canadian Journal of Forest Research 25: 1652-1657. - doi: 10.1139/x95-179

Gonet S, Debska B, Dziamski A, Banach-Szott M, Zaujec A, Szombathova N (2009). Properties of organic matter in haplic luvisol under arable, meadow and forest management. Polish Journal of Soil Science 42 (2): 139-148.

Gorlach E, Mazur T (2001). Agricultural chemistry: basics of nutrition and principles of fertilization. PWN, Warsaw, Poland, pp. 125. [in Polish]

Griffiths R, Madritch M, Swanson A (2005). Conifer invasion of forest meadows transforms soil characteristics in the Pacific Northwest. Forest Ecology and Management 208: 347-358. doi: 10.1016/j.foreco.2005.01.015

Holubík O, Podrázsky V, Vopravi J, Khel T, Remeš $J$ (2014). Effect of agricultural lands afforestation and tree species composition on the soil reaction, total organic carbon and nitrogen content in the uppermost mineral soil profile. Soil and Water Research 9 (4): 192-200. - doi: 10.17221/104/2013-SWR

Innangi M, Danise T, D'Alessandro F, Curcio E, Fioretto A (2017). Dynamics of organic matter in leaf litter and topsoil within an italian alder (Alnus cordata (Loisel.) Desf.) ecosystem. Forests 8 (240): 1-16. - doi: 10.3390/f8070240

Jobbágy EG, Jackson RB (2003). Patterns and mechanisms of soil acidification in the conversion of grasslands to forests. Biogeochemistry 64: 205-229. - doi: 10.1023/A:1024985629259 Jonczak J (2013). Soil organic matter properties in stagnic luvisols under different land use types. Acta Agrophysica 20 (4): 565-576. [online] URL: http://yadda.icm.edu.pl/yadda/elem ent/bwmeta1.element.agro-41a97acd-f6da-4a7 6-8681-82c24658ad7e

Jonczak J, Parzych A, Sobisz Z (2015). Decomposition of four tree species leaf litters in headwater riparian forest. Baltic Forestry 21 (1): 133-143. [online] URL: http://www.balticforestry.mi.It/ bf/PDF_Articles/2015-21[1]

Jonczak J, Olejniczak M, Parzych A, Sobisz Z (2016). Dynamics, structure and chemistry of litterfall in headwater riparian forest on the area of Middle Pomerania. Journal of Elementology 21 (2): 381-392. - doi: 10.5601/jelem.2015. 20.3.938

Krzaklewski W, Pietrzykowski M, Wos B (2012). Survival and growth of alders (Alnus glutinosa (L.) Gaertn. and Alnus incana (L.) Moench) on fly ash technosols at different substrate improvement. Ecological Engineering 49: 35-40. . org. - doi: 10.1016/j.ecoleng.2012.08.026

Lu D, Moran E, Mausel P (2002). Linking Amazonian secondary succession forest growth to soil properties. Land Degradation Development 13: 331-343. - doi: 10.1002/ldr.516

Maly S, Fiala P, Reininger D, Obdrálková E (2014). The relationships among microbial parameters and the rate of organic matter mineralization in forest soils, as influenced by forest type. Pedobiologia 57: 235-244. - doi: 10.1016/j.pedobi.20
14.09.003

Matuszko D (2007). The climate of Krakow in the $20^{\text {th }}$ century. Institute of Geography and Spatial Management of the Jagiellonian University, Krakow, Poland, pp. 251. [in Polish]

Miletić Z, Kneević M, Stajić S, Košanin O, Dordević I (2012). Effect of European black alder monocultures on the characteristics of reclaimed mine soil. International Journal of Environmental Research 6 (3): 703-710.

Mishra G, Giri K, Dutta A, Hazarika S, Borgohain P (2016). Short communication: a laboratory study to validate the impact of the addition of Alnus nepalensis leaf litter on carbon and nutrients mineralization in soil. Nusantara Bioscience 8 (1): 5-7. - doi: 10.13057/nusbiosci/no 8 0102

Monnier G, Turc L, Jeanson-Lunsiuang C (1962). Une methode de fractionnement densimetrique pour centrifugation des matiers organiques du sol [A densimetric fractionation method for centrifugation of soil organic matter]. Annales Agronomique 13: 55-63. [in French]

Moran E, Brondizio ES, Tucker JM, Silva-Forsberg M, McCracken S, Falesi I (2000). Effects of soil fertility and land-use on forest succession in Amazonia. Forest Ecology and Management 139: 93-108. - doi: 10.1016/S0378-1127(99)003370

Niemyska-Lukaszuk J, Zaleski T, Mazurek R, Szwagrzyk J, Bodziarski J, Podwika M (2001). Characteristics of the soil and habitat conditions of the municipal forests of Kraków. W. Szafer Foundation for Polish Botany, Krakow, Poland, pp. 22.

Orczewska A, Piotrowska A, Lemanowicz J (2012). Soil acid phosphomonoesterase activity and phosphorus forms in ancient and post-agricultural black alder (Alnus glutinosa (L.) Gaertn.) woodlands. Acta Societatis Botanicorum Poloniae 81 (2): 81-86. - doi: 10.5586/asbp. 2012.013

Ostrowska A, Gawlinski S, Szczubialka Z (1991). Procedures for soil and plants analysis. Institute of Environmental Protection, Warsaw, Poland, pp. 333. [in Polish]

Ross DJ, Tate KR, Scott NA, Feltham CW (1999). Land-use change: effects on soil carbon, nitrogen and phosphorus pools and fluxes in three adjacent ecosystems. Soil Biology and Biochemistry 31: 803-813. - doi: 10.1016/S0038-0717 (98)00180-1

Sinha S, Masto RE, Ram LC, Selvi VA, Srivastava NK, Tripathi RC, George J (2009). Rhizosphere soil microbial index of tree species in a coal mining ecosystem. Soil Biology and Biochemistry 41: 1824-1832. - doi: 10.1016/j.soilbio.2008. 11.022

Schulp CJE, Nabuurs G-H, Verburg PH, De Waal RW (2008). Effect of tree species on carbon stocks in forest floor and mineral soil and implications for soil carbon inventories. Forest Ecology and Management 256: 482-490. - doi: 10.1016/j.foreco.2008.05.007

Smal H, Ligeza S, Olszewska M (2004). The effect of afforestation of sandy post-arable soils on the quality of organic matter and chemical composition of soil solution. Soil Science Annual 55 (4): 139-148.

Smal H, Olszewska M (2008). The effect af- 
forestation with Scots pine (Pinus silvestris L.) of sandy post-arable soils on their selected properties. II. Reaction, carbon, nitrogen and phosphorus. Plant and Soil 305: 171-187. - doi: 10.1007/s11104-008-9538-z

Tan KH (2005). Soil sampling, preparation and analysis. Taylor and Francis Group, Boca Raton, London, New York, Singapore, pp. 408. [online] URL: http://www.taylorfrancis.com/books/9781 482274769

Tanner LH, Smith DL, Curry J, Twist J (2014). Effect of land use change on carbon content and
$\mathrm{CO}_{2}$ flux of cloud forest soils, Santa Elena, Costa Rica. Open Journal of Soil Science 4: 6471. - doi: 10.4236/ojss.2014.42009

Temperton VM, Grayston SJ, Jackson G, Barton CVM, Millard P, Jarvis PG (2003). Effects of elevated carbon dioxide concentration on growth and nitrogen fixation in Alnus glutinosa in a long-term field experiment. Tree Physiology 23: 1051-1059. - doi: 10.1093/treephys/23.15.1051

Uri V, Lõhmus K, Mander U, Ostonen I, Aosaar J, Maddison M, Helmisaari HS, Augustin J (2011). Long-term effects on the nitrogen budget of a short-rotation grey alder (Alnus incana (L.) Moench) forest on abandoned agricultural land. Ecological Engineering 37: 920-930. - doi: 10.1016/j.ecoleng.2011.01.016

Vesterdal L, Schmidt IK, Callesen I, Nilsson LO, Gundersen P (2008). Carbon and nitrogen in forest floor and mineral soil under six common European tree species. Forest Ecology and Management 255: 35-48. - doi: 10.1016/j.foreco. 2007.08.015

WRB (2015). Soil resources reports 106. WRB recommendations, FAO-UN, Rome, Italy, pp. 192. 